\title{
Nutritive value of 15 single pollens and pollen mixes tested on larvae produced by bumblebee workers (Bombus terrestris, Hymenoptera: Apidae)*
}

\author{
Jean-Noël TASEI ${ }^{1}$, Pierrick AUPINEL $^{2}$ \\ ${ }^{1}$ INRA, Laboratoire de zoologie, route de Saintes, 86600 Lusignan, France \\ ${ }^{2}$ INRA, Unité expérimentale d'entomologie, Le Magneraud, 17700 Surgères, France \\ Received 6 November 2007 - Revised 25 January 2008 - Accepted 7 February 2008
}

\begin{abstract}
Laboratory trials were performed at $27^{\circ} \mathrm{C}$ on micro-colonies comprised of three Bombus terrestris workers. They were fed with syrup and pollen paste ad libitum. The micro-colonies were terminated on the 14th day after egg-laying. Two bioassays tested the nutritive value of 6 pure pollens and 9 commercial pollen mixes on bumblebee larvae. Among 10 criteria tested, the most sensitive to the different pollens were the mean weight of larvae and the rate of discarded larvae. Differentiation between treatments was easier with single pollens that ranged from $14.4 \%$ to $24.9 \%$ crude protein for Helianthus and Castanea respectively, than with mixes that ranged from $12.9 \%$ to $17.6 \%$. The best performance ranking was assigned to Castanea, Papaver and Rubus, which produced larvae weighing 110-150 mg, the lowest to Helianthus and Cistus which resulted in larvae of 20-50 mg. The largest larvae $(240 \mathrm{mg})$ were produced with the mix at $96 \%$ Brassica and $15.9 \%$ protein and the smallest with the mix at the lowest protein content (12.9\%) assembling Picris, Hedera, Amaranthus, Solanum, Helianthus and graminaceae.
\end{abstract}

Bombus terrestris / Bumble bee / larva / nutritive value / pollen

\section{INTRODUCTION}

Dietetic requirements of carbohydrates, lipids, vitamins and proteins for the honeybee have been reviewed by Haydak (1970), and the importance of proteins in bee biology has been detailed by de Groot (1953). Pain (1968), Örösi Pal (1968) and Haydak (1968) emphasized the role of protein in the development of sexual organs and hypopharyngial and mandibular glands of adults, and in the nutrition of larvae. It is well known that the main source of protein during the life cycle of all bee species is pollen collected from flowers. The nutritive value of pollen varies according to the plant and is usually roughly estimated by the crude protein content, which lies within the

Corresponding author: J.N. Tasei, Jean-Noel.Tasei@lusignan.inra.fr

* Manuscript editor: Marla Spivak range $2.5 \%-61 \%$ according to Roulston et al. (2000). A number of bioassays comparing the value of pollen or pollen substitutes have been reported on honeybees by authors who considered various parameters, namely: haemolymph protein (Cremonez et al., 1998); ovary development, body weight and body size (Hoover et al., 2006); sexual maturation and number of spermatozoa (Nguyen, 1999); brood rearing capacity (Campana and Moeller, 1977; Loper and Berdel, 1980); hypopharyngial glands of young adults (McCaughey et al., 1980; Szymas and Przybyl, 1996; Pernal and Curie, 2000); and adult longevity (Haydak, 1970; Kleinschmidt and Kondos, 1978; Nguyen, 1999).

Few studies on solitary bees have been published: Levin and Haydak (1957) tested the nutritive value of several pollens by measuring the mortality of larvae and the peak weight of surviving Osmia lignaria; whereas Roulston 
and Cane (2002) assessed the body weight of adult Lasioglossum zephyrum fed pollen diets with different protein concentrations.

Some scientists investigated the role of pollens in the development of bumblebee colonies (Plowright and Pendrel, 1977; Sutcliffe and Plowright, 1988; Duchateau and Velthuis 1989; Ribeiro et al., 1993; Regali and Rasmont, 1995; Ribeiro et al., 1996; Genissel et al., 2002). These authors tested pollens based mainly on the following criteria: egg production, body size of adults, larva weight, adult mortality and longevity, brood rearing capacity and sperm production of males. More recent contributions dealing with the nutritive quality of collected honeybee pollen fed to bumblebees reflect the concern about the quality of the food supplied to bumblebee colonies reared in artificial conditions. Pollen nutritive value is considered as one of the key factors of mass bumblebee rearing, which started commercially in Europe in 1987 (Velthuis and Van Doorn, 2006).

Regali and Rasmont (1995) were the first to describe a method using queenless microcolonies of workers to test the effects of pollen mixes on food consumption and development of male brood from young larvae to adults. Ribeiro et al. (1996) fed pollen mixes to queenright colonies and measured the weight and number of workers, males and queens. They also assessed the survival of new queens and their egg laying capabilities. Genissel et al. (2002) used queenless micro-colonies and 17 criteria to compare the effects of 3 single pollens and one mix on larval development and male fitness. A common objective of these three representative studies was to assess the nutritive value of pollens on the number and quality of adult offspring. As a consequence the test response was delayed beyond three months or even one year when the criterion was the quality of new queens (Ribeiro et al., 1996).

Based on the above approaches using queenless micro-colonies (Regali and Rasmont, 1995; Genissel et al., 2002), our goal was to design a simpler, faster and more sensitive method for routinely comparing the nutritive value of pollens. With this in mind, the observation period was restricted to the
2 weeks following egg-laying by the dominant worker, which covers the complete larval development.

The objectives of our study were: (i) To compare the sensitivity of 10 criteria for testing the nutritive value of pollens on the larvae produced by queenless micro-colonies of workers, (ii) To test the quality of six pure pollens belonging to different plant families and of nine commercial pollen mixes similar to those which are currently used by bumblebee producers in Europe.

\section{MATERIALS AND METHODS}

\subsection{Bumblebee management}

Our tests used micro-colonies of three callow workers Bombus terrestris reared in a climate room $\left(27{ }^{\circ} \mathrm{C}, 70 \% \mathrm{RH}\right.$ and a photoperiod: D8: L16) according to the methods described by Tasei and Aupinel (1994) and Genissel et al. (2002). Everyday workers less than 1 day old were collected from among 10 young queenright colonies of the ecotype from southeastern France and were gathered in a single box. At the end of each daily collection, groups of three workers were assigned to the same number of rearing boxes per treatment. These plywood boxes were rectangular $(11 \times 5 \times 5 \mathrm{~cm})$ with a screened floor and a transparent cover.

Food was provided ad libitum. Micro-colonies were fed a commercial syrup, $37 \%$ sucrose and $38 \%$ fructose and dextrose, supplied in small bird feeders. Pollen was provided as $1-2 \mathrm{~g}$ balls prepared by mixing pollen pellets collected by honeybees with sugar syrup (70\% and 30\% w/w respectively), which resulted in a pollen paste at $75 \%$ dry matter. The balls were dipped into liquid beeswax to prevent the pollen from drying and facilitate weighing. Before use waxed balls were stored at $-30^{\circ} \mathrm{C}$. When needed, a ball was introduced into a box and placed in a round $3 \mathrm{~cm}$ diameter dish.

In micro-colonies one of the three workers usually became dominant, played the role of a false queen and built an egg-cell within 2 weeks. Workers attended their brood by supplying food and building and heating larval cells. Sometimes they destroyed the initial egg-cell or discarded young larvae instead of feeding them.

\subsection{Observations}

Every day in each micro-colony we recorded the number of dead workers, the presence of an 
egg-cell, its possible destruction and the number of ejected larvae. When a worker died it was replaced by a worker of the same age. We weighed pollen balls before their introduction into the box and their wax cover when pollen was totally consumed. Micro-colonies were terminated on the 14th day after egg-laying and returned to the laboratory for the counting and the weighing of larvae. At this time all the larvae had reached the last instar, spun their cocoon and were not yet pupae. The nitrogen content of experimental pure pollens or mixes was measured on $50 \mathrm{mg}$ paste samples according to Dumas' method, using a Leco apparatus for analysis (Watson and Galliher, 2001).

\subsection{Experiments}

In our two experiments each treatment was replicated 10 to 13 times.

\subsubsection{Experiment 1}

In 2000 six pre-selected commercial pollen samples were purchased from Pollenergie France. The pollen, collected from honey bee colonies, is currently supplied by beekeepers who are urged to trap pollen in particular areas and periods. Pollenergie sorts the incoming batches with high proportions of a major pollen species and stores them at $-30{ }^{\circ} \mathrm{C}$ before sale for human consumption. Our samples showed high percentages of Castanea sativa, Actinidia sinensis, Cistus sp., Papaver rheas, Helianthus annuus, and Rubus sp., respectively. Before use the packages were stored in a freezer at $-30{ }^{\circ} \mathrm{C}$.

We obtained six pure experimental pollens ready for preparing the diets. Pellets were selected by colour which resulted in $100 \%$ purity, confirmed by microscopic check.

\subsubsection{Experiment 2}

In 2001 nine commercial mixes were provided by two bumblebee companies which purchased them from beekeepers of southwestern France. The companies needed quality testing of the nutritive value of the pollens and chose the best ones for feeding their queens and colonies. Comparison was made by using the same micro-colony method and protocol as in experiment 1 . In each mix the floral origin of pollens was determined through microscopic examination. To prepare the slides we used a method inspired from Maurizio and Louveaux
(1965): we made a water suspension with a representative sample of about 100 pellets, then after stirring the solution, a drop was deposited on a slide, dried, cleaned with ether and inbedded with a glycerin-gelatin medium coloured with fuchsin. Pollens were identified by comparison with reference slides using a 400 magnification. Percentages of each type were established by counting 1000 grains. Proportions by volume were calculated after correcting the percentages by the size of each type estimated by the mean diameter of 20 grains (Tasei, 1973).

\subsection{Criteria of pollen quality}

Ten criteria were tested relating to (i) Number and size of larvae (weight of larvae per microcolony, mean weight of larvae), (ii) Losses (worker mortality, discarded larvae, oophagy and egg-cell destruction), (iii) Pollen consumption and efficacy (pollen consumption by workers during the 5 days preceding egg laying, pollen consumption during the 14 days after egg laying, pollen efficacy, protein efficacy). Pollen and protein efficacies were estimated by the quotients: weight of live larvae produced / pollen consumed and weight of live larvae produced / protein consumed, respectively.

\subsection{Statistics}

The data presented as means \pm s.d. were interpreted with Kruskal-Wallis test or ANOVA analyses followed by LSD or Tukey tests respectively, for pair-wise comparisons of treatments.

When percentages had to be compared a Chisquare test was used. When Chi-square revealed a significant effect, all the combinations of paired comparisons were tested through Chi-square analysis.

We used the statistical program Minitab 10.5 (Minitab Inc, 1996).

\section{RESULTS}

\subsection{Botanical origin of pollen mixes}

We considered as main genera the more abundant pollens that represented more than $32 \%$ of the mix by volume. Secundary genera were those between $10 \%$ and $32 \%$ of the mix. Each minor genus accounted for less than $10 \%$ and the summation of all minor genera in a mix never exceeded $30 \%$ of the total mix. (Tab. I). 
Table I. Botanical origin (plant genera or family) of nine commercial pollen mixes used in experiment 2. Proportions by volume between brackets were calculated from numerical proportions corrected by the diameter of pollen grains of each plant species.

\begin{tabular}{|c|c|c|c|}
\hline $\begin{array}{l}\text { Pollen mix } \\
\text { code }\end{array}$ & $\begin{array}{l}\text { Main species } \\
(>32 \%)\end{array}$ & Secondary species ( $10 \%$ to $32 \%$ ) & Others $(<10 \%)$ \\
\hline $\mathrm{A}$ & Salix (73.9) & Prunus (14.8) & $\begin{array}{l}\text { Brassica }(5.6) \\
\text { Malus }(2.9) \\
\text { Taraxacum }(2.8)\end{array}$ \\
\hline B & Picris (32.6) & $\begin{array}{l}\text { Hedera }(16.0), \text { Solanum }(13.7) \\
\text { Amaranthus }(11.6)\end{array}$ & $\begin{array}{l}\text { Helianthus }(9.0) \\
\text { Graminaceae }(9.0) \\
\text { Plantago }(2.2) \\
\text { Cruciferae }(1.8) \\
\text { Unknown }(4.1)\end{array}$ \\
\hline $\mathrm{C}$ & Brassica (76.9) & Prunus (10.0) & $\begin{array}{l}\text { Quercus }(9.5) \\
\text { Salix }(1.8) \\
\text { Taraxacum }(1.4) \\
\text { Unknown }(0.4)\end{array}$ \\
\hline $\mathrm{D}$ & Prunus (47.8) & Papaver (23.6) & $\begin{array}{l}\text { Actinidia }(7.2) \\
\text { Cruciferae }(4.6) \\
\text { Picris }(3.7) \\
\text { Tilia }(2.9) \\
\text { Trifolium }(2.3) \\
\text { Hedera }(2.1) \\
\text { Erica }(1.9) \\
\text { Geranium }(1.6) \text { Unknown }(1.2) \\
\text { Carduus }(0.8)\end{array}$ \\
\hline $\mathrm{E}$ & Prunus (63.9) & Brassica (31.9) & $\begin{array}{l}\text { Taraxacum }(2.1) \\
\text { Salix }(2.0) \\
\text { Rhamnus }(0.1)\end{array}$ \\
\hline $\mathrm{F}$ & Brassica (34.4) & $\begin{array}{l}\text { Rubus }(20.8) \\
\text { Hedera }(14.8)\end{array}$ & $\begin{array}{l}\text { Helianthus }(9.2) \\
\text { Plantago }(7.3) \\
\text { Taraxacum }(4.7) \text { Unknown (3.9) } \\
\text { Amaranthus }(3.2) \\
\text { Lotus }(1.6)\end{array}$ \\
\hline G & Quercus (58.4) & Brassica (20.6) & $\begin{array}{l}\text { Malus }(9.4) \\
\text { Salix }(3.0) \\
\text { Aesculus }(2.5) \\
\text { Vicia }(2.2) \\
\text { Sinapis }(2.1) \text { Unknown }(1.2) \\
\text { Sambucus }(0.6)\end{array}$ \\
\hline $\mathrm{H}$ & Brassica $(95.8)$ & & $\begin{array}{l}\text { Rosaceae (2.5) } \\
\text { Sinapis (1.6) }\end{array}$ \\
\hline I & Salix (93.2) & & $\begin{array}{l}\text { Rosaceae }(2.3) \\
\text { Quercus }(1.7) \\
\text { Hedera }(1.1) \\
\text { Brassica }(1.1) \text { Corylus }(0.6)\end{array}$ \\
\hline
\end{tabular}


The types of main pollens were: Salix in mixes A and I, Picris in mix B, Brassica in mixes $\mathrm{C}, \mathrm{F}, \mathrm{H}$, Prunus in mixes $\mathrm{D}$ and $\mathrm{E}$, Quercus in mix G. The number of pollens ranged from 3 in mix $\mathrm{H}$ to 12 in mix D. Apart from the 5 main pollens cited above, 20 other pollen types were identified: Malus, Taraxacum, Hedera, Solanum, Amaranthus, Plantago, Papaver, Actinidia, Tilia, Trifolium, Lotus, Vicia, Erica, Geranium, Carduus, Rubus, Rhamnus, Aesculus, Sinapis, Sambucus and two were unidentified Graminaceae and Cruciferae pollens.

\subsection{Nitrogen and protein contents of pollen diets}

Tables II and III show the results of nitrogen analyses of pollen pastes. Protein contents were calculated by applying the multiplying factor 6.25 to nitrogen values as recommended by Roulston and Cane (2002).

The pastes with the highest nitrogen content (\% dry weight) were those of 2 pure pollens: Papaver (3.98 \pm 0.15$)$ and Castanea (3.25 \pm 0.04) whereas the pastes of Cistus and $\mathrm{He}$ lianthus $(2.31 \pm 0.03$ and $2.30 \pm 0.26)$ had the lowest nitrogen contents. Rubus (3.08 \pm 0.07$)$ and Actinidia $(2.91 \pm 0.15)$ ranked at an intermediate level.

Nitrogen contents of mixed pastes ranged from $2.06 \pm 0.3$ for mix "B", to $2.82 \pm 0.08$ for mix “G”.

\subsection{Effects of pollen treatments on microcolonies}

\subsubsection{Pure pollen diet treatments (Tab. IV)}

Parameters that did not respond to treatment significantly at $P<0.05$ were: (i) the number of live larvae produced per micro-colony, (ii) pollen consumption by workers before egglaying, (iii) protein efficacy i.e. weight of larvae/protein consumed in 14 days, (iv) egg cell destruction.

Other parameters showed significant differences between treatments: a/ Weight of the larvae produced per microcolony $(P=0.04)$. Castanea resulted in the highest weight of larvae produced $(0.71 \mathrm{~g})$. This was significantly more than Helianthus (0.06 g).

b/ Mean individual weight of larvae $(P<$ $0.01)$. The biggest larvae were produced when fed Castanea $(0.15 \mathrm{~g})$, the smallest with $\mathrm{He}$ lianthus (0.02 g), Cistus (0.05 g), Actinidia (0.09 g) which produced larvae significantly bigger than Helianthus. Rubus and Papaver resulted in intermediate individual weights ( $0.11 \mathrm{~g}$ and $0.12 \mathrm{~g}$ respectively) significantly higher than when fed Cistus or Helianthus.

c/ Percentage of non-attended larvae $(P<$ $0.001)$. The highest larval ejection rates were observed in treatments with Papaver (27\%) and Helianthus (22.4\%) and the lowest in treatments with Castanea $(4.5 \%)$ and Rubus (6\%). The rate with Actinidia (10.8\%) was significantly lower than with Papaver.

d/ Pollen consumption $(P=0.03)$. During the 14 days following egg-laying Papaver was less consumed than Helianthus $(2.05 \mathrm{~g}$ and $3.67 \mathrm{~g}$ respectively). Other pollens resulted in intermediate consumptions within the range $2.63-3.17 \mathrm{~g}$.

e/ Worker mortality $(P=0.01)$. The highest percentage of workers which died and were replaced during the experiment was found in Helianthus treatment $(25.6 \%)$. Significant lower percentages were obtained with Castanea (7.7\%), Rubus (7.7\%), Papaver (5.1\%), Actinidia (2.6\%). Cistus resulted in $12.8 \%$ which was not different from any other treatment.

f/ Pollen efficacy $(P=0.005)$. Papaver and Castanea were significantly more efficient than Helianthus (Efficacy quotients: $0.32,0.31,0.02$, respectively).

\subsubsection{Treatments with pollen mix diets (Tab. V)}

Parameters that did not respond to treatments were: (i) Weight of larvae per microcolony, (ii) Number of live larvae per microcolony, (iii) Pollen consumption during the 14 days following egg-laying, (iv) Worker 
Table II. Nitrogen and protein content in the pollen paste fed to bumble bees in experiment 1: six pure pollen species were tested. Three samples per pollen paste were analysed. Values bearing the same letters are not significantly different at $P<0.05$, according to Kruskal-Wallis test followed by LSD test for multiple comparisons.

\begin{tabular}{lll}
\hline Pollen type (100\% purity ) & Nitrogen content $(\%$ dry weight \pm sd) & Protein content $(\%$ dry weight $)$ \\
\hline Actinidia & $2.91 \pm 0.15$ (a) & 18.1 \\
Cistus & $2.31 \pm 0.03$ (b) & 14.4 \\
Papaver & $3.98 \pm 0.07$ (c) & 24.9 \\
Helianthus & $2.30 \pm 0.26$ (b) & 14.4 \\
Castanea & $3.25 \pm 0.04$ (c) & 20.3 \\
Rubus & $3.08 \pm 0.07$ (a) & 19.2 \\
\hline
\end{tabular}

Table III. Nitrogen and protein content in the pollen paste fed to bumble bees in experiment 2: nine pollen mixes were tested (cf: Tab. I). Two samples per pollen paste were analysed and no statistical analysis could be supplied.

\begin{tabular}{lll}
\hline Pollen mix code & Nitrogen content $(\%$ dry weight $\pm \mathrm{sd})$ & Protein content $(\%$ dry weight $)$ \\
\hline A & $2.46 \pm 0.06$ & 15.4 \\
B & $2.06 \pm 0.30$ & 12.9 \\
C & $2.62 \pm 0.01$ & 16.4 \\
D & $2.45 \pm 0.13$ & 15.3 \\
E & $2.62 \pm 0.09$ & 16.4 \\
F & $2.29 \pm 0.11$ & 14.3 \\
G & $2.82 \pm 0.08$ & 17.6 \\
H & $2.54 \pm 0.07$ & 15.9 \\
I & $2.40 \pm 0.07$ & 15.0 \\
\hline
\end{tabular}

mortality, (v) Pollen efficacy, (vi) Protein efficacy, (vii) Egg-cell destruction.

Three parameters discriminated some of the 9 mixes:

a/ Mean weight of larvae $(P=0.005)$.

The larvae produced by mix "H" (Brassica $95.8 \%)$ were heavier $(0.24 \mathrm{~g})$ than those produced in treatment "B" (Picris 32.6\%) which weighed $0.08 \mathrm{~g}$. The 7 other mixes resulted in larval weights ranging between $0.11 \mathrm{~g}$ and $0.23 \mathrm{~g}$ and therefore did not show any significant difference.

b/ Percentage of non-attended larvae $(P<$ 0.001).

The proportions of ejected larvae with mix "C" (Brassica 76.9\%) and "G" (Quercus $58.4 \%$ ) were $37.4 \%$ and $37.1 \%$ respectively, which was higher than with all other mixes ranging between $7.0 \%$ and $17.4 \%$. c/ Pollen consumption by workers before egg-laying $(P=0.009)$.

Food consumption with mixes "F" (Brassica $34.4 \%$ ) and "I" (Salix 93.2\%), was $0.62 \mathrm{~g}$ and $0.67 \mathrm{~g}$ respectively which was higher than with mix "E" (Prunus 63.9\%) at $0.35 \mathrm{~g}$. Other consumptions ranged between $0.44 \mathrm{~g}$ and $0.58 \mathrm{~g}$.

\section{DISCUSSION}

\subsection{Parameters}

Our test method involved 20 to 40 day experiments, using about 10 queenless microcolonies of three workers. In our study with pure pollens and mixes, two parameters provided discriminating data that enabled pollen 


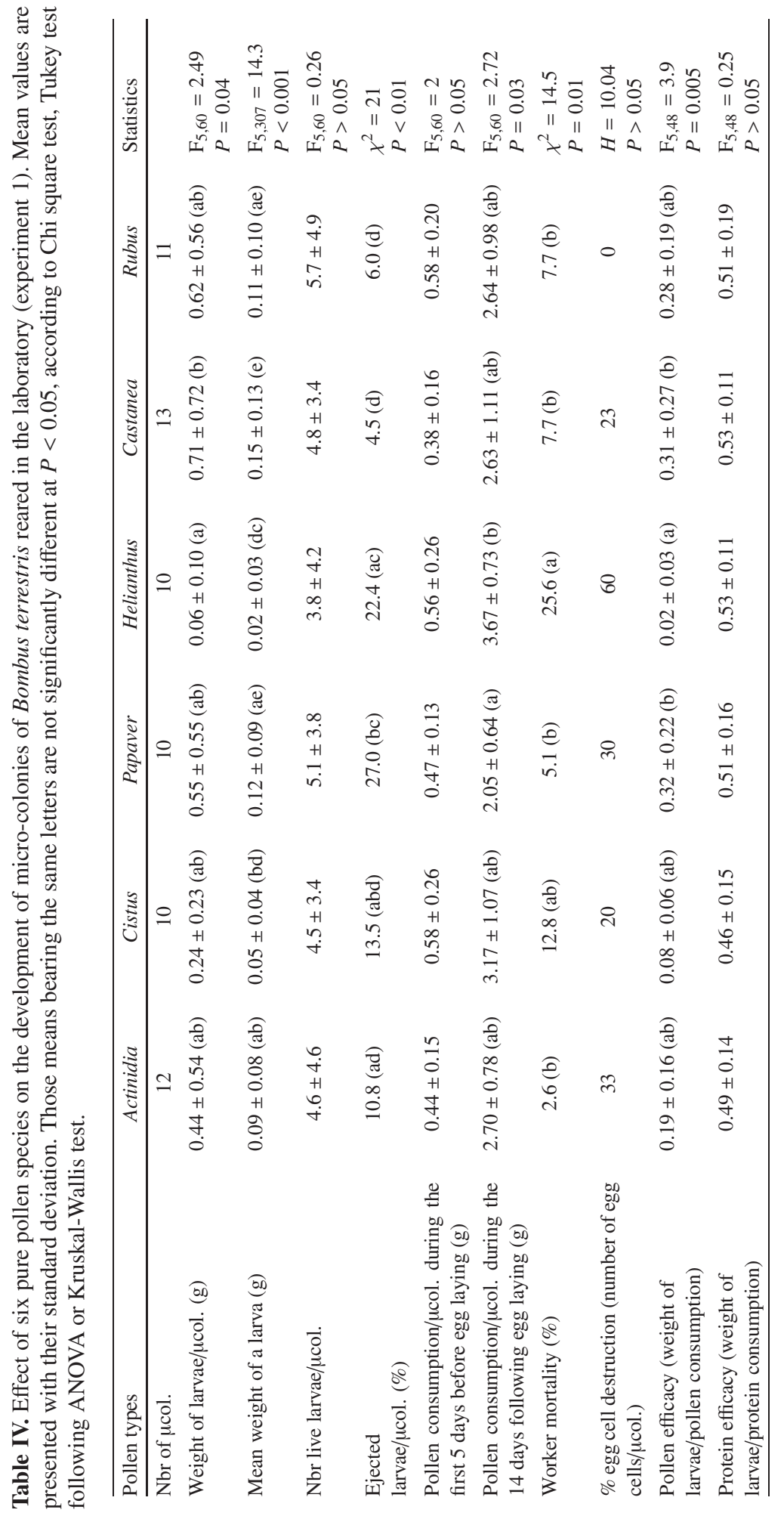




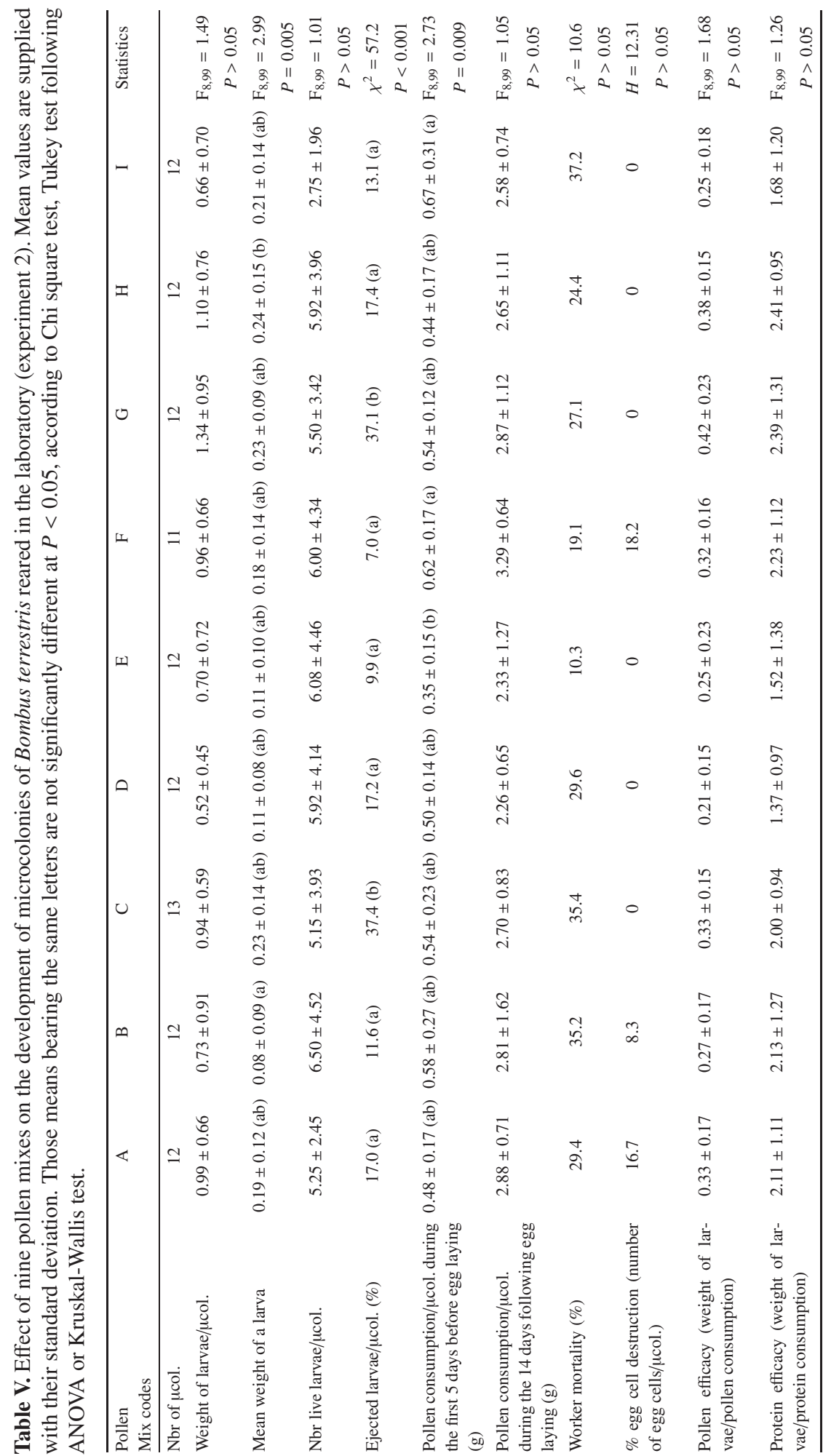


ranking: the mean weight of a larva and the ejection rate of larvae. These results are consistent with the literature showing that body size is an early parameter, usually reflecting the protein level of bee food (Ribeiro, 1994; Nguyen, 1999; Roulston and Cane, 2002) whereas ejection of larvae by workers was considered discriminating only by Genissel et al. (2002).

No significant difference was shown by the protein efficacy criterion, which was the ratio: weight of larvae / protein consumption during brood feeding. Nevertheless the protein efficacy was approximately four times higher with mixes, than with single pollens. Previously, the only authors to consider such a parameter were Levin and Haydak (1957).

The number of live larvae per micro-colony and the rate of egg-cell destruction did not allow the discrimination between the treatments of our study, although oophagy and egg-cell destruction by workers showed significant differences between protein rich and poor diets (Weiss, 1984; Genissel et al., 2002) and is generally interpreted as a compensation for the lack of pollen proteins in honeybees or bumblebees.

Four other parameters revealed significant differences but only between single pollens: worker mortality, weight of larvae per microcolony, pollen consumption during brood feeding and pollen efficacy; whereas pollen consumption by workers before egg-laying allowed the differentiation between some mixes.

\subsection{Pollens and protein contents}

In the experiment with the six single pollens, Castanea performed the best according to five criteria and Helianthus showed the lowest nutritive value according to 6 criteria. With regard to three important parameters: mean larval weight, brood attendance and worker mortality, Rubus ranked close to Castanea. The larval mean weight provided the best discrimination between single pollens and showed that the best performances were observed with Castanea, Papaver and Rubus, and the lowest with Cistus and Helianthus. Actinidia was an intermediate diet. This ranking is in accordance with their nitrogen content. The satisfactory results obtained with Actinidia suggested that a major proportion of pellets was collected from male kiwi flowers instead of female plants which provide sterile grains, and showed a weak nutritive value with regard to ovary development in honeybee workers according to Jay and Jay (1993).

Several authors provided consistent information on the effect of two Compositae with a low protein level: Taraxacum and Helianthus on the larval development of three bee species. Levin and Haydak (1957) found that Taraxacum hindered complete larval development of Osmia lignaria whereas Herbert et al. (1970) and Loper and Berdel (1980) stated that no brood could be produced by Taraxacum fed honeybees, while Genissel et al. (2002) observed high rates of oophagy and $100 \%$ larval ejection in bumblebee micro-colonies fed with this single pollen. Loper and Berdel (1980) and Loper and Cohen (1987) assumed that poor brood rearing capabilities by new honeybee workers fed pure Taraxacum were due to deficiencies or inadequate ratios of at least four amino-acids. Pure Helianthus fed to honeybees reduced adult longevity (Schmidt et al., 1995) and resulted in a low development of hypopharyngeal glands of new workers (Pernal and Currie, 2000). Moreover Singh et al. (1999) found antifeedant compounds in Helianthus lipids.

In the experiment with the nine mixes, the number of significant responses from the 10 parameters was much lower than in the experiment with single pollens, which may be due to the restricted range of nitrogen concentrations $(2.06 \%-2.82 \%)$ and $(2.30 \%-3.98 \%)$, respectively. In addition, the three discriminative parameters, mean larval weight, larval ejection rate and pollen consumption by workers before egg-laying, did not provide consistent results and consequently, quality ranking of the mixes was not possible. Nevertheless it has been shown that mixes "B", "C" and "G" resulted in significant negative effects on larvae either in terms of larval size or larval ejection. Presumably Picris dominance (32.6\%) in mix "B" along with the assemblage of Hedera, Amaranthus, Solanum, Helianthus and graminaceae accounting for $59 \%$ of the mix, were 
not favourable to the production of normal larvae, in contrast to mix "A" with $96 \%$ Brassica. In mixes " $C$ " and "G" larval ejection might have been triggered by the presence of Quercus pollen (9.5\% and $58.4 \%$ respectively). Mix "I" consisting of $93.2 \%$ Salix and mix "F" assembling 4 pollens representing 79\%: Brassica, Rubus, Hedera and Helianthus were both consumed more by pre-ovipositing workers than mix "E", consisting of $95.8 \%$ Prunus and Brassica, which suggests theses diets had a lower efficacy.

Considering both experiments, two Compositae genera: pure Helianthus and Picris as the dominant pollens in mix "B", affected the size of larvae which weighed less than $0.10 \mathrm{~g}$, whereas other single pollens and pollen mixes resulted in larval weights of $0.05 \mathrm{~g}-$ $0.150 \mathrm{~g}$ and $0.110 \mathrm{~g}-0.240 \mathrm{~g}$ respectively. Among the 15 diets tested over the two trials, pure Helianthus pollen paste and Picris mix had the lowest nitrogen concentrations, $2.30 \%$ and $2.06 \%$ respectively. However, in the same laboratory conditions larvae consuming mix "B" were heavier $(0.08 \mathrm{~g})$ than those fed Helianthus $(0.02 \mathrm{~g})$, which suggested that nitrogen content was not the only component of pollen nutritive value and that a mix compared to a single pollen of similar nitrogen content, may provide additional nutritive properties due to the presence of other pollens. This would explain why mean larval weights of the second experiment were higher with the 6 mixes: "A", "C", "F", "G", "H", "I" of lower nitrogen content than with the 3 pure pollens Castanea, Papaver and Rubus.

Protein content is generally considered as a good index of nutritive value. Nevertheless Pernal and Currie (2000) recommended conducting bioassays before making conclusions about pollen quality. It has long been known that bee growth and development as well as reproduction, require proteins, lipids and vitamins (Stanley and Linskens, 1974). In addition, specific statements support Pernal and Currie's recommendation: in their review Roulston and Cane (2000) referred to differences of nitrogen assimilation efficiencies between bee species; Herbert et al. (1980) demonstrated the importance of lipids in bee diets; and Levin and Haydak (1957) assumed that deficiences in cholesterol and vitamins "B" might have affected larval development in Osmia lignaria when fed with Sarcobatus pollen.

From a field experiment with bumblebees, Rasheed and Harder (1997) stated that foragers of three Bombus species could maximize their pollen collection efficiency by using their sensitivity to both protein availability and foraging cost. However according to Pernal and Currie's (2001) honeybee foragers were insensitive to pollen quality and responded to quality deficiencies in their hive stores by increasing the gross amount of pollen collected regardless of its protein content. Kleinschmidt and Kondos (1978) found that honeybees compensated for low protein level of the pollen stored in their hive by increasing pollen consumption so that the body protein content (parameter correlated with adult longevity) did not fall below $40 \%$.

Such an ability to compensate for protein deficiencies of diets was also observed in our study with pure pollens by the two parameters related to consumption. The diet with the highest protein rate (Papaver, 24.9\%) was significantly less consumed during the 14-day nursing period than the diet with the lowest rate (Helianthus, 14.1\%), and similar amounts of Castanea (20.3\% protein) and Papaver diet yielded higher weights of larvae per microcolony than Helianthus diet. In the trial with mixes the same parameters indicated no significant difference, probably due to the more restricted range of protein rates $(12.9 \%-17.6 \%)$ and nutritive values estimated by mean larval weights within the range $0.080 \mathrm{~g}-0.240 \mathrm{~g}$.

Rigorous extrapolation of the conclusions drawn from a micro-colony test on queenright colonies would be justified only after a validation experiment where the same test pollens supplied to queenright colonies and queenless micro-colonies would produce similar effects on the two sets of colonies. There are good grounds to expect that testing of pollens by micro-colonies will predict their effects on the development of queenright colonies and the quality of the new queens. 


\section{ACKNOWLEDGEMENTS}

Many thanks are due to Erick Rivault and Véronique Delassaire for their technical assistance during this research, to Monique Bucher for providing the nitrogen contents of our pollen samples, to Yves Loublier (INRA, Bures-sur-Yvette) for helping in pollen identification and to Jane Le Saout for linguistic advices.

Évaluation de la valeur nutritive de 15 pollens et mélanges de pollens testés sur des larves produites par des ouvrières de bourdons (Bombus terrestris, Hymenoptera : Apidae).

\section{Bombus terrestris / larve / pollen / valeur nutri- tive}

Zusammenfassung - Nährwertbestimmung von 15 Einzelpollen und Pollengemischen durch Tests an von Hummelarbeiterinnen produzierten Larven (Bombus terrestris, Hymenoptera: Apidae). Der Nährwert von Pollen, der von Honigbienen gesammelt wurde, stellt einen Schlüsselfaktor für die kommerzielle Hummelzucht dar. Wir wollten eine einfache, schnelle und empfindliche Methode entwickeln, mit der man routinemäßig den Nährwert verschiedener Pollen vergleichen kann. Die Ziele unserer Studie waren: (i) Ein Vergleich der Empfindlichkeit der vorhandenen Kriterien zum Test der Nährwerte von Pollen bei der Produktion von Larven in weisellosen Mikro-Völkern mit Arbeiterinnen; (ii) Ein Test der Qualität von 6 Pollen, die zu verschiedenen Pflanzenfamilien gehören und von 9 kommerziellen Pollengemischen, die derzeit von Hummelzüchtern benützt werden.

Für die Tests wurden Mikro-Völker mit drei Bombus terrestris Arbeiterinnen in kleinen Kästen $(11 \times$ $5 \times 5 \mathrm{~cm}$ ) benutzt, die bei $27{ }^{\circ} \mathrm{C}, 70 \% \mathrm{RF}$ und einem Dunkel-Licht-Rhythmus von D8 : L16 gehalten wurden. Pollen und Zuckerwasser wurden ad libitum angeboten. Der Pollen wurde als Paste in 1$2 \mathrm{~g}$-Bällchen angeboten. Neun Diäten mit kommerziellen Pollengemischen, die aus Honigbienenvölkern gesammelt wurden und 6 Diäten mit nur einer Pollensorte wurden den Mikro-Völkern gefüttert und die Versuche 10 bis 13 mal wiederholt. Die Hauptpollen in den Gemischen waren: Salix, textitPicris, Brassica, Prunus, Quercus (Tab. I).

Einzelpollen waren: Castanea, Actinidia, Cistus, Papaver, Helianthus und Rubus. Über folgende Kriterien wurde der Nährwert bestimmt: (i) Eiweißgehalt anhand der Stickstoff-Bestimmung, (ii) Anzahl und Größe der Larven (Gewicht der Larven pro Mikro-Volk, mittleres Gewicht der Larven), (iii) Verluste (Arbeiterinnenmortalität, ausgeräumte Larven, Oophagie und Zerstörung von Eizellen), (iv) Pollenaufnahme und Effektivität der Pollenverwendung (Pollenaufnahme durch Arbeiterinnen während der 5 Tage vor Eiablage, Pollenaufnahme während der 14 Tage nach Eiablage, Polleneffektivität, Eiweißeffektivität). Die Pollen- und Eiweißeffektivität wurden durch den Quotienten „Gewicht der produzierten lebenden Larve / Pollen- bzw. Eiweißaufnahme" bestimmt.

Zwei aus Einzelpollen gebildete Pasten wiesen den höchsten Stickstoffgehalt auf: Papaver $(3,98 \%)$ und Castanea $(3,25 \%)$. Pasten aus Cistus und $\mathrm{He}$ lianthus $(2,31 \%$ und $2,30 \%)$ hatten den geringsten Gehalt, während Rubus $(3,08 \%)$ und Actinidia $(2,91 \%)$ dazwischen lagen. Der Stickstoffgehalt von gemischten Pasten reichte von 2,06 \% für Mix B, bis 2,82 \% für Mix G. (Tabs. II und III).

Castanea, Papaver und Rubus produzierten die größten Larven $(0,15 \mathrm{~g}, 0,12 \mathrm{~g}$ and $0,11 \mathrm{~g})$, während Actinidia, Cistus und Helianthus die kleinsten hervorbrachte $(0,09 \mathrm{~g}, 0,05 \mathrm{~g}$ bzw. 0,02). Die höchsten Larvenausräumraten wurden bei Fütterung mit $\mathrm{Pa}$ paver $(27 \%)$ und Helianthus $(22,4 \%)$ beobachtet, die geringsten bei Fütterung mit Castanea (4,5\%) und Rubus (6\%). Darüber hinaus gab es bei 4 weiteren Kriterien Unterschiede (Tab. IV).

Bezüglich einiger der 9 Mischungen traten nur bei drei Parametern Unterschiede auf: durchschnittliches Larvengewicht, Entfernen von Larven und Futterverbrauch durch die Arbeiterinnen. Obwohl keine klare Rangordnung bezüglich der Qualität der Mischungen aufgestellt werden konnte, scheint es, dass Mischungen mit hohem Anteil an Picris oder Quercus einen Effekt auf die Larven haben (Tab. V). Die wichtigsten Parameter in einem solchen Bruttest sind das durchschnittliche Larvengewicht und die Ausräumrate der Larven 14 Tage nach Eiablage. Einzelpollen sind leichter zu vergleichen als Mischungen. Pollen von Compositae ist von eindeutig schlechter Qualität. Es muss geprüft werden, ob Tests in Mikro-Völkern eine Vorhersage bezüglich des Nährwertes von Pollen in weiselrichtigen Völkern erlauben.

\section{Bombus terrestris / Hummeln / Larven / Nähr- wert / Pollen}

\section{REFERENCES}

Campana B.J., Moeller F.E. (1977) Honeybees: preference for and nutritive value of pollen from five plant sources, J. Econ. Entomol. 70, 39-41.

Cremonez T.M., Jong D. De, Bitondi M.M.G. (1998) Quantification of haemolymph proteins as a fast method for testing protein diets for honeybees (Hymenoptera: Apidae), J. Econ. Entomol. 91, 1284-1289.

Duchateau M.J., Velthuis H.H.W. (1989) Ovarian development and egg laying in workers of Bombus terrestris, Entomol. Exp. Appl. 51, 199-213. 
Genissel A., Aupinel P., Bressac C., Tasei J.N., Chevrier C. (2002) Influence of pollen origin on performance of Bombus terrestris micro-colonies, Entomol. Exp. Appl. 104, 329-336.

Groot A.P. de (1953) Protein and amino acid requirements of the honeybee (Apis mellifera L.), Physiol. Comp. Oecol. 3, 197-285.

Haydak M.H. (1968) Nutrition des larves d'abeilles, in: R. Chauvin (Ed.), Traité de Biologie de l'Abeille, Vol. 1, Masson et Cie, Paris, pp. 302333.

Haydak M.H. (1970) Honey bee nutrition, Ann. Rev. Entomol. 15, 143-156.

Herbert E.W., Bickley W.E., Shimanuki H. (1970) The brood-rearing capability of caged honey bees fed dandelion and mixed pollen diets, J. Econ. Entomol. 63, 215-218.

Herbert E.W. Jr., Shimanuki H., Shasha B.S. (1980) Brood rearing and food consumption by honeybee colonies fed pollen substitutes supplemented with starch encapsulated pollen extracts, J. Apic. Res. 19, 115-118.

Hoover S.E.R., Higo H.A., Winston M.L. (2006) Worker honey be ovary development: seasonal variation and the influence of larval and adult nutrition, J. Comp. Physiol. B 176, 55-63.

Jay S.C., Jay D.H. (1993) The effect of kiwifruit (Actinidia deliciosa A Chev) and yellow flowered broom (Cystisus scoparius Link) pollen on the ovary development of worker honeybees (Apis mellifera L), Apidologie 24, 557-563.

Kleinschmidt G.J., Kondos A.C. (1978) The effect of dietary protein on colony performance, Aust. Beekeeper June, 251-257.

Levin M.D., Haydak M.H. (1957) Comparative value of different pollens in the nutrition of Osmia lignaria, Bee World 38, 221-226.

Loper G.M., Berdel R.L. (1980) The effects of nine pollen diets on brood rearing of honeybees, Apidologie 11, 351-359.

Loper G.M., Cohen A.C. (1987) Amino acid of dandelion pollen, a honeybee (Hymenoptera: Apidae) nutritional evaluation, J. Econ. Entomol. 80, 1417.

McCaughey W.F., Gilliam M., Standifer L.N. (1980) Amino acids and protein adequacy for honeybees of pollens from desert plants and other floral sources, Apidologie 11, 75-86.

Maurizio A., Louveaux J. (1965) Pollens de plantes mellifères d'Europe, Union des Groupements Apicoles Français, Paris.

Nguyen V.N. (1999) Effect of protein nutrition and pollen supplementation of honeybee, Apis mellifera L. colonies on characteristics of drones with particular refernece to sexual maturity, Aust. Beekeeper Mar., 374-376.

Örösi Pal Z. (1968) Physiologie des glandes nourricières, in: R. Chauvin (Ed.), Traité de Biologie de l'Abeille, Vol. 1, Masson et Cie, Paris, pp. 263290.
Pain J. (1968) Nutrition et développement des organes sexuels adultes, in: R. Chauvin (Ed.), Traité de Biologie de l'Abeille, Vol. 1, Masson et Cie, Paris, pp. 410-435.

Pernal S.F., Currie R.W. (2000) Pollen quality of fresh and 1-year-old single pollen diets for worker honey bees (Apis mellifera L.), Apidologie 3, 387409.

Pernal S.F., Currie R.W. (2001) The influence of pollen quality on foraging behavior in honeybees (Apis mellifera L.), Behav. Ecol. Sociobiol. 51, 53-68.

Plowright R.C., Pendrel R.A. (1977) Larval growth in bumblebees (Hymenoptera: Apidae), Can. Entomol. 109, 967-973.

Rasheed S.A., Harder L.D. (1997) Economic motivation for plant species preferences of pollen collecting bumblebees, Ecol. Entomol. 22, 209-219.

Regali A., Rasmont P. (1995) Nouvelles méthodes de test pour l'évaluation du régime alimentaire chez des colonies orphelines de Bombus terrestris L. (Hymenoptera: Apidae), Apidologie 26, 273-281.

Ribeiro M. (1994) Growth in bumble bee larvae: relation between development time, mass, and amount of pollen ingested, Can. J. Zool. 72, 1978-1985.

Ribeiro M., Velthuis H.H.W., Duchateau M.J. (1993) Growth in bumblebee larvae: relations between the age of the larvae, their weight and the amount of pollen ingested by them, Proc. Exp. Appl. Entomol. N.E.V. Amsterdam 4, 121-125.

Ribeiro M., Duchateau M.J., Velthuis H.H.W. (1996) Comparison of the effects of two kinds of commercially available pollen on colony development and queen production in the bumblebee Bombus terrestris L. (Hymenoptera: Apidae), Apidologie 27, 133-144.

Roulston T.H., Cane J.H., Buchmann S.L. (2000) What governs protein content of pollen: pollinator preferences, pollen-pistil interactions, or phylogeny? Ecol. Monogr. 70, 617-643.

Roulston T.H., Cane J.H. (2000) Pollen nutritional content and digestibility for animals, Plant Syst. Evol. 222, 187-209.

Roulston T.H., Cane J.H. (2002) The effect of pollen protein concentration on body size in the sweat bee Lasioglossum zephyrum (Hymenoptera: Apiformes), Evol. Ecol. 16, 49-65.

Schmidt L.S., Schmidt J.O., Rao H., WeiYi W., Ligen X. (1995) Feeding preference and survival of young worker honeybees (Hymenoptera: Apidae) fed rape, sesame, and sunflower pollen, J. Econ. Entomol. 88, 1591-1595.

Singh S., Saini K., Jain K.L. (1999) Quantitative comparison of lipids in some pollens and their phagostimulatory effects in honeybees, J. Apic. Res. 38, 87-92.

Stanley R.G., Linskens H.F. (1974) Pollen- Biology Biochemistry Management, Springer-Verlag, Berlin, Heidelberg, New-York.

Sutcliffe G.H., Plowright R.C. (1988) The effects of food supply on adult size in the bumble bee 
Bombus terricola Kirby (Hymenoptera: Apidae), Can. Entomol. 120, 1051-1058.

Szymas B., Przybyl A. (1996) Physiological condition of worker bees (Apis mellifera L.) after consumption of pollen substitute, Psczczelnicze Zeszyty Naukowe 40, 109-117.

Tasei J.N. (1973) Le comportement de nidification chez Osmia (Osmia) cornuta Latr. et Osmia (Osmia) rufa L. (Hymenoptera: Megachilidae), Apidologie 4, 195-225.

Tasei J.N., Aupinel P. (1994) Effect of photoperiodic regimes on the oviposition of artificially overwintered Bombus terrestris L. queens and the production of sexuals, J. Apic. Res. 33, 27-33.
Velthuis H.H.M., van Doorn A. (2006) A century of advances in bumblebee domestication and the economic and environmental aspects of its commercialization for pollination, Apidologie 37, 421451.

Watson M.E., Galliher T.L. (2001) Comparison of Dumas and Kjeldahl methods with automatic analyzers on agricultural samples under routine rapid analysis conditions, Commun. Soil Sci. Plan. 32, 2007-2019.

Weiss K. (1984) Regulation of protein balance in the honeybee colony by brood cannibalism, Apidologie 15, 339-353. 